\title{
PROFIL BERPIKIR SISWA MI DALAM PEMECAHAN MASALAH PECAHAN DITINJAU DARI GAYA BELAJAR
}

\author{
Khurin'in Ratnasari \\ DosenTetap PGMI INAIFAS KencongJember \\ khurininratnasari@gmail.com
}

\begin{abstract}
This paper aims to describe the profile of thinking of MI students in solving fraction problems in terms of learning styles. In this paper the visual subject and subject of Audiotori are the same about how to understand the problem by reading the problem in a slow or loud voice as much as once or repeatedly, expressing the problem in their own words, repeating things that are known and explaining according to their own language, given other knowledge that has been it has or a concept that has been mastered to make a plan that is by adding it up and remembering the plan that has been made by raising the idea to start working on the problem of the problem given, make a plan that will be used in solving the problem by implementing the plan made, storing information that is by saying repetitive plans made and repeating the implementation of the plan.
\end{abstract}

Keywords: profile thinking, algebra problem solving, learning style.

\section{PENDAHULUAN}

Matematika sebagai salah satu cabang ilmu yang dinilai dapat memberikan konstribusi positif dalam memacu ilmu pengetahuan dan teknologi. Menurut Soedjadi, matematika sebagai salah satu ilmu dasar, baik aspek terapannya maupun aspek penalarannya mempunyai peranan yang penting dalam upaya penguasaan ilmu dan teknologi. Sehingga matematika menjadi sangat penting dalam upaya peningkatan mutu pendidikan. Ini berarti bahwa sampai batas tertentu matematika perlu dikuasai oleh siswa, baik penerapannya maupun pola pikirnya. $^{1}$

. Menurut Susanto proses berpikir merupakan suatu proses yang dimulai dari masuknya informasi atau penemuan informasi dari luar diri siswa, mengolah

1 Soedjadi, R. (2000). Kiat Pendidikan Matematika Di Indonesia. Konstatasi Keadaan Masa Kini Menuju Harapan Masa Depan, Jakarta: Direktorat Jendral Pendidikan Tinggi, Departemen Pendidikan Nasional.

FalASIFA, Vol. 9 Nomor 1 Maret 2018 | 35 
informasi, penarikan kesimpulan, dan pemanggilan kembali informasi itu dari ingatan ketika dibutuhkan ${ }^{2}$.

Materi matematika MI terdiri dari bilangan bulat, pecahan, geometri, dan statistik. Pecahan merupakan salah satu materi yang dikenalkan mulai kelas III MI. Menurut Orton pecahan merupakan suatu bagian penting dari kurikulum pendidikan dasar. Hampir semua dari apa yang diajarkan tentang pecahan di MI diajarkan kembali di sekolah menengah. Oleh karena itu pembelajaran siswa tentang pecahan di MI harus optimal. Konsep pecahan serta operasi-operasinya harus benar-benar dipahami siswa dengan tepat. ${ }^{3}$

Operasi pecahan mulai dikenalkan di kelas IV MI. Operasi yang pertama kali dipelajari adalah operasi penjumlahan dan pengurangan. Sebelum siswa mempelajari operasi penjumlahan dan pengurangan, terlebih dahulu mereka harus memahami pecahan senilai. Proses pembelajaran operasi pecahan. Sebaiknya dilakukan seperti mengenalkan pecahan. Siswa dibimbing untuk mengkonstruksi pengetahuan mereka sendiri. Apabila siswa mampu mengkonstruksi pengetahuannya sendiri, maka pengetahuan yang dimiliki siswa akan lebih kuat dan dapat digunakan untuk menyelesaikan masalah yang lebih kompleks.

Kenyataan di lapangan, banyak siswa yang hanya menghafalkan rumus untukmenyelesaikan masalah matematika. Hal ini sesuai dengan hasil penelitian yangdilakukan oleh Holisin (2012) yaitu:

Kebanyakan siswa hanya menghafal rumus tanpa memahami makna dari rumustersebut. Sesuai dengan tahap perkembangan kognitif yang dikemukakan olehPiaget, bahwa siswa kelas I-IV berada pada tahap operasional konkret. Sedangkankelas V dan VI merupakan peralihan dari tahap operasional konkret ke tahapoperasional formal. Pada usia ini, siswa memiliki proses berpikir lebih baik.Dalam hal ini, kaitannya dengan berpikir siswa dalam memecahkan masalahpecahan dapat dikatakan berbeda-beda, salah satunya disebabkan oleh gaya belajar. ${ }^{4}$ Hasrul (2009) berpendapat bahwa adanya dua kategori utama tentang bagaimanasiswa belajar. Pertama, bagaimana siswa menyerap informasi dengan mudah(modalitas). Dan kedua, cara mengatur dan mengelola informasi

2 Susanto. (2008). Mahasiswa Field Independent dan Field Dependent Dalam Memabami Konsep Grup. Semnas matematika dan pendidikanmatematika: Universitas Negeri Yogyakarta

${ }^{3}$ Orton, A. (1992).Learning mathematics issues, theory and classroom practice.

(Sec. ed.). London: Cassell.

${ }^{4}$ Holisin, L. (2012). Profil Penalaran Siswa Sekolah Dasar Dalam Menyelesaikan masalah pecahan ditinjan dari perbedaan gender dan kemampuan matematika. (Disertasi doktor tidak dipublikasikan). Universitas NegeriSurabaya.

36 | FaLASIFA, Vol. 9 Nomor 1 Maret 2018 
tersebut (dominasi otak). ${ }^{5}$ Hasrul berendapat bahwa gaya belajar merupakan kombinasi dari bagaimana seseorang menyerap kemudian mengatur serta mengolah informasi.

Mengetahui gaya belajar siswa sangatlah penting, sebagian siswa mungkin memiliki gaya belajar yang sesuai dengan gaya mengajar guru, namun mungkin juga banyak yang tidak demikian. Bagi siswa yang memiliki gaya belajar yang tidak sesuai dengan gaya mengajar guru, kemungkinan tidak dapat menangkap informasi atau pengetahuan yang disampaikan. Untuk itulah guru harus mengetahui gaya belajar siswanya sehingga siswa lebih mengerti dengan materi yang disampaikam dan dapat menangkap materi yang disampaikan oleh guru Menurut Gunawan secara umum ada 7 pendekatan gaya belajar yang dikenal, namun yang paling mudah diidentifikasi dan dijumpai adalah gaya belajar dengan pendekatan Modalitas Sensori yang dikembangkan oleh Bandler dan Grinder. Karena pada saat siswa belajar pasti menggunakan panca indra. ${ }^{6}$

Dengan modalitas sensori kita bisa melihat langsung karakteristik gaya belajar siswa dan mudah mengidentifikasi gaya belajar siswa. Terdapat 3 jenis gaya belajar menurut pendekatan Modalitas Sensori yaitu visual (penglihatan), auditori (pendengaran) dan kinestetik (sentuhan dan gerakan). Alasan memilih pendekatan berdasarkan modalitas sensori adalah : pada saat belajar, indera pertama kali digunakan untuk menerima informmasi.

Berdasarkan penjelasan diatas, maka penulis tertarik untuk mengadakan penelitian yang bertemakan berpikir siswa MI dalam pemecahan masalah matematika. Adapun judul penelitian ini adalah: "Profil Berpikir Siswa MI Dalam Pemecahan Masalah Pecahan Ditinjau Dari Gaya Belajar.

\section{PEMBAHASAN}

\section{Berpikir}

Berpikir adalah anugerah yang diberikan Tuhan kepada manusia untuk membedakan manusia dengan makhluk lain. Zainab (2012) berpendapat bahwa manusia berpikir untuk menemukan pemahaman atau pengertian, pembentukan pendapat, dan kesimpulan atau keputusan dari sesuatu yang dikehendaki. ${ }^{7}$ Berpikir

${ }^{5}$ Hasrul. (2009). "Pemahaman Tentang Gaya Belajar" Volume 1, No 2 Jurnal.

Online) http://ftunm.net/medtek/Jurnal\%20Medtek/Hasrul.pdf, diakses pada tanggal 14 November 2015.

${ }^{6}$ Gunawan. A. W. (2006). Genius Learning Strategy. Jakarta: Gramedia Pustaka Utama.

${ }^{7}$ Zainab. (2012). Matematika Sebagai Alat Berpikir Pada Aljabar.

http://blog.unsri.ac.id/zainab2011/filsafat-pendidikan/matematika-sebagai-alat-

FaLASIFA, Vol. 9 Nomor 1 Maret 2018 | 37 
biasanya dimulai dengan adanya pertanyaan atau masalah yang perlu untuk diselesaikan atau dijawab. Pertanyaan tersebut bisa berupa apa, mengapa, dimana, kapan, dan lain sebagainya.

Solso mengungkapkan bahwa berpikir adalah proses yang membentuk representasi mental baru yang melalui transformasi informasi oleh interaksi kompleks dari atribusi mental yang mencakup pertimbangan, pengabstrakan, penalaran, penggambaran, pemecahan masalah logis, pembentukan konsep, kreativitas dan kecerdasan. Lebih lanjut Solso mengemukakan bahwa ada tiga ide dasar tentang berpikir, yaitu: (1) berpikir bersifat kognitif, terjadi secara "internal", dalam pemikiran namun keputusan diambil lewat perilaku, (2) berpikir adalah proses yang melibatkan beberapa manipulasi pengetahuan dalam sistem kognitif, (3) berpikir bersifat langsung dan menghasilkan perilaku yang "memecahkan" masalah atau langsung menuju padasolusi. ${ }^{8}$ Santrock (2010) juga menambahkan bahwa berpikir adalah memanipulasi atau mengelolah dan mentransformasi informasi dalam memori. ${ }^{9}$

\section{Masalah dan Pemecahan Masalah}

Sebelum membahas masalah pecahan, terlebih dahulu diuraikan tentang pengertian masalah. Masalah dapat diartikan sebagai situasi atau pertanyaan yang dihadapi seorang individu atau kelompok ketika mereka tidak mempunyai aturan, algoritma/prosedur tertentu atau hukum yang segera dapat digunakan untuk menemukan jawabannya (Siswono, 2008). ${ }^{10}$ Siswono juga menambahkan ciri-ciri suatu masalah bagi seorang individu sebagai berikut: (1) individu yang bersangkutan menyadari/mengenali suatu situasi (pertanyaan-pertanyaan) yang dihadapi (membutuhkan pengetahuan prasyarat), (2) individu tersebut menyadari bahwa situasi tersebut membutuhkan tindakan (menantang), (3) langkah pemecahan suatu masalah tidak harus jelas atau mudah diterima oleh orang lain. ${ }^{11}$

Sedangkan, menurut Sumardyiono masalah adalah kesenjangan antara

berpikir-pada-aljabar/mrdetail/101949.Diakses pada tanggal 18 November 2015.

${ }^{8}$ Solso., dkk. (2008). Psikologi Kognitif. Edisi kedelapan. Erlangga.

${ }^{9}$ Santrock, J. W. (2010). Psikologi Pendidikan Edisi Kedua. Jakarta: Kencana.

${ }^{10}$ Siswono, T. Y.E. (2008). Model Pembelajaran Matematika Berbasis Pengajuandan

Pemecaban Masalah Untuk Meningkatkan Kemampuan Berpikir Kreatif. Surabaya. Unesa University Press.

${ }^{11}$ Siswono, T. Y. E (2002). Proses Berpikir Siswa Dalam Pengajuan Soal. Jurnal Matematika Atau Pembelajarannya, Tahun VIII. ISSN:0852-7792, Universitas Negeri Malang Konferensi Nasional Matematika XI. http://tatagyes.files.wordpress. com/2009/11/paper02 berpikir2.Pdf. Download Pada tanggal 16 November 2015.

38 | FaLASIFA, Vol. 9 Nomor 1 Maret 2018 
Profil Berpikir Siswa MI dalam Pemecahan masalah...

harapan dan kenyataan. ${ }^{12}$ Namun dalam matematika istilah "masalah" memiliki makna yang lebih khuusus. Kata "masalah" terkait erat dengan suatu pendekatan pembelajaran yaitu pendekatan pemecahan masalah. Lebih lanjut dia menyatakan bahwa tidak setiap soal dapat disebut masalah. Ciri-ciri suatu soal disebut masalah dalam perspektif ini paling tidak memuat 2 hal yaitu: 1) soal tersebut menantang pikiran,2)soal tersebut tidak otomatis diketahui cara penyelesaiannya. Dalam matematika seseorang yang menghadapi masalah dalam suatu soal harus berusaha secara maksimal untuk menemukan cara yang tepat untuk memecahkan/menyelesaikan soal /masalah tersebut guna memperoleh jawaban.

Berdasarkan beberapa pendapat di atas, maka yang dimaksud masalah dalam penelitian ini adalah situasi yang berupa pertanyaan/soal matematika non rutin yang membutuhkan penyelesaian dan jalan/cara untuk memperoleh penyelesaian tersebut tidak diketahui secara langsung. Jadi masalah pecahan adalah situasi yang berupa pertanyaan/soal matematika non rutin yang terkait dengan pecahan yang membutuhkan penyelesaian dan jalan/cara untuk memperoleh penyelesaian tersebut tidak diketahui secara langsung

Sejalan dengan pengertian masalah, Polya mendefinisikan pemecahan masalah sebagai usaha mencari jalan keluar dari situasi kesulitan, mencapai suatu tujuan yang tidak dengan segera dapat dicapai. Selanjutnya Solso mengatakan "problem solving is thinking that is directed toward the solving of aspecific problem that involves both the formation of responses and the selection among possible responses”. Yang artinya, pemecahan masalah adalah aktivitasberpikir yang diarahkan pada menyelesaikan suatu masalah tertentu yang melibatkan baik pembentukan responrespon maupun pemilihan diantara respon-respon yang mungkin. ${ }^{13}$

Sedangkan menurut Krulik \& Rudnick (1995:4) "It[problem solving] is the means by which an individual uses previously acquired knowledge, skills, and understanding to satisfy the demands of an unfamiliar situation”. Yang artinya ini [pemecahan masalah] adalah sarana yangmemungkinkan seorang individu menggunakan pengetahuan yang diperoleh sebelumnya, keterampilan keterampilan, dan pemahaman untuk memenuhi tuntutan dari situasi yang tidak familiar. ${ }^{14}$ Dengan memperhatikan beberapa pendapat tersebut, maka yang

\footnotetext{
${ }^{12}$ Sumardyono. (2011). Pengertian Dasar Problem Solving. https://erlisilitonga.files. wordpress.com/2011/12/pengertiandasarproblems olving smd.pdf.Diakses, 16 November 2015.

${ }^{13}$ Polya, G. (1973). How To Solve It. A new Aspect of Mathematical Method. Princetown University Press. Princeton and Oxford.

${ }^{14}$ Krulik, S \& Rudnick, J. A. (1995). The new sourcebook for teachingreasoning and problem solving in Elementary School.Boston:Allyn andBacon.
}

FaLASIFA, Vol. 9 Nomor 1 Maret 2018 | 39 


\section{Khurin'in Ratnasari}

dimaksud pemecahan masalah dalam penelitian ini adalah usaha seorang individu mencari jalan keluar dari situasi kesulitan, mencapai suatu tujuan yang tidak dengan segera dapat dicapai dengan menggunakan pengetahuan yang diperoleh sebelumnya, keterampilan-keterampilan, dan pemahaman.

Polya (1973) menjelaskan langkah-Iangkah pemecahan masalah terdiri dari

(1) memahami masalah (understanding the problem), (2) membuat rencana penyelesaian (devising a plan), (3) menyelesaikan rencana penyelesaian (carryingout the plan), dan (4) memeriksa kembali (looking back). Langkah-langkahpemecahan masalah menurut Polya (1973) secara terperinci adalah sebagai berikut.

a. Memahami Masalah (understanding the problem)

Langkah-Iangkah yang dapat digunakan untuk memahami masalah adalah dengan mengidentifikasi hal-hal yang diketahui dan yang ditanyakan dalam soal (masalah).

b. Membuat Rencana (devising a plan)

Langkah-langkah yang dapat digunakan untuk membuat rencana adalah dengan mengajukan beberapa pertanyaan. Misalnya: apakah kamu pernah melihat masalah ini sebelumnya? Atau apakah kamu pernah melihat masalah yang mirip dengan masalah ini? apakah kamu mengetahui masalah yang berkaitan? Apakah kamu mengetahui cara yang dapat digunakan untuk menyelesaikan masalah?

c. Melaksanakan Rencana (carrying out the plan)

Langkah-langkah yang dapat digunakan untuk melaksanakan rencana adalah meminta subjek melaksanakan rencana penyelesaian yang telah dibuat; Mengecek setiap langkah; mengajukan pertanyaan apakah tahapannya benar? Apakah hasil pada setiap langkah masuk akal? Dapatkah kamu membuktikan bahwa tahapannya benar?

d. Memeriksa Kembali (looking back)

Langkah-langkah yang dapat digunakan untuk memeriksa kembali adalah dengan meminta subjek untuk memeriksa hasil akhir; memeriksa proses secara keseluruhan; Bila proses diulangi apakah menghasilkan hasil yang sama? Dapatkah kamu memeriksa alasannya? Dapatkah kamu menghasilkan penyelesaian dengan cara yang berbeda? Apakah hasilnya nampak terbaca? Dapatkah kamu menggunakan hasilnya, atau metodenya untuk masalahmasalah yang lain?

5) Melaksanakan Rencana (carrying out the plan)

Langkah-langkah yang dapat digunakan untuk melaksanakan rencana adalah 
meminta subjek melaksanakan rencana penyelesaian yang telah dibuat; Mengecek setiap langkah; mengajukan pertanyaan apakah tahapannya benar? Apakah hasil pada setiap langkah masuk akal? Dapatkah kamu membuktikan bahwa tahapannya benar?

6) Memeriksa Kembali (looking back)

Langkah-langkah yang dapat digunakan untuk memeriksa kembali adalah dengan meminta subjek untuk memeriksa hasil akhir; memeriksa proses secara keseluruhan.

Sementara itu menurut Krulik \& Rudnick (1995) langkah pemecahan masalah terdiri dari:

1. Membaca dan berpikir (read and think); meliputi langkah-langkah sebagai berikut: Identifikasi fakta informasi yang diberikan; Identifikasi pertanyaan; Visualisasi situasi/informasi; Menguraikan setting; dan Menyatakan kembali tindakan.

2. Mengeksplorasi dan merencanakan (explore and plan); meliputi langkahlangkah sebagai berikut: Mengorganisir informasi; Apakah informasi sudah cukup? Apakah terlalu banyak informasi? Gambar diagram atau susun suatu model; dan Buat diagram, table, grafik, atau menggambar.Menyeleksi suatu strategi (select a strategy); meliputi langkah-langkah sebagai berikut: Pengenalan pola; Bekerja mundur; Duga dan uji Simulasi atau percobaan; Reduksi dan ekspansi; Daftar terorganisasi; Deduksi logis; Bagi dan selesaikan.

3. Mencari jawaban (find and answer); meliputi langkah-langkah sebagai berikut: Estimasi; Gunakan keahlian menghitung; Gunakan keahlian aljabar; Gunakan keahlian geometri (gunakan kalkulator apabila sesuai).

4. Merefleksi dan memperluas (reflect and extend); meliputi langkah-langkah sebagai berikut: Cek jawaban anda (Apakah perhitungannya betul? Apakah pertanyaan sudah terjawab? Apakah jawabannya masuk akal? Bagaimana cara membandingkan jawaban dengan perkiraanmu?); Temukan solusi pengubah; Apa akibatnya jika ....? Memperluas untuk yang lain (generalisasi, konsep matematika); Mendiskusikan solusi; Ciptakan variasi yang menarik pada masalah yang asli.

Hayes (dalam Solso:1995) menjelaskan langkah-langkah pemecahan masalah itu terdiri dari: (1) Mengidentifikasi masalah (Identifying the problem); (2) Representasi masalah (Representation of the problem); 3) Perencanaan solusi (Planning the solution); (4) Jalankan rencana (Execute the plan); (5) Evaluasirencana (Evaluate the plan); (6) Mengevaluasi solusi (Evaluate the solution).

Berdasarkan beberapa pendapat di atas, maka pada penelitian ini akan

FaLASIFA, Vol. 9 Nomor 1 Maret 2018 | 41 
menggunakan fase-fase pemecahan masalah menurut Polya, dengan alasan aktivitas-aktivitas pada setiap fase yang dikemukakan Polya secara implisit mencakup semua fase yang dikemukakan ahli yang lain. Misalnya langkah mengidentifikasi masalah dan representasi masalah (menurut Hayes) termuat pada langkah memahami masalah (menurut Polya). Langkah mengeksplorasi \& merencanakan dan memilih suatu strategi (Krulik \& Rudnick) termuat pada langkah membuat rencana (Polya).

\section{METODE PENELITIAN}

Penelitian ini termasuk dalam jenis penelitian kualitatif, yaitu penelitian yang menggunakan data kualitatif kemudian dideskripsikan untuk menghasilkan gambaran yang jelas dan terperinci tentang berpikir siswa MI dalam memecahkan masalah pecahan yang ditinjau dari gaya belajar.

Subjek penelitian adalah siswa kelas V MI yang sudah mempelajari materi Bilangan Pecahan yang meliputi pengenalan pecahan, pecahan senilai, penjumlahan, pengurangan, perkalian, dan pembagian pecahan. Peneliti memilih subjek kelas V MI, karena di kelas V semua materi pecahan dan operasinya sudah diajarkan seluruhnya, sehingga diharapkan siswa dapat menyelesaikan berbagai masalah pecahan. Selain itu siswa kelas V MI dipandang cukup komunikatif untuk diwawancarai guna diselidiki berpikinya dalam memecahkan masalah pecahan.

\section{Tahap Perencanaan}

Pada tahap ini, kegiatan yang dilakukan adalah:

a) Mempersiapkan dan merancang instrumen tes gaya belajar, tes tertulis dan pedoman wawancara.

b) Melaksanakan validasi terhadap instrumen penelitian tes tertulis.

c) Menganalisis hasil validasi instrumen penelitian kemudian merevisi instrumen tersebut.

\section{Tahap Pengambilan Data}

Pada tahap ini, kegiatan yang dilakukan adalah:

a) Memberikan tes gaya belajar untuk memperoleh siswa yang gaya belajarnya auditori, siswa yang gaya belajarnya visual dan siswa yang gaya belajarnya kinestetik.

b) Menentukan subjek penelitian yang memenuhi setiap kriteria.

c) Memberikan tes tertulis terhadap subjek penelitian untuk memperoleh data profil berpikir subjek penelitian.

d) Melakukan wawancara dengan subjek penelitian berdasarkan data hasil tes tertulis, untuk mendapatkan data yang lebih mendalam tentang profil berpikir subjek penelitian.

\section{2 | FaLASIFA, Vol. 9 Nomor 1 Maret 2018}




\section{Tahap Analisis Data}

Pada tahap ini, kegiatan yang dilakukan adalah:

a) Menganalisis data hasil tes gaya belajar.

b) Menganalisis data hasil tes tertulis dan hasil wawancara.

c) Mendeskripsikan hasil analisis tes tertulis dan hasil wawancara.

\section{Tahap Pembuatan Laporan}

Penulisan laporan hasil penelitian tidak terlepas dari keseluruhan tahapan kegiatan dan unsur-unsur penelitian. Pada tahap ini kegiatan yang dilakukan adalah menyusun kerangka dan isi laporan, penulisan laporan, dan penelaahan hasil penelitian. Prosedur penelitian disajikan dalam Diagram di bawah ini:

\section{HASIL DAN PEMBAHASAN}

Hasil penelitian ini menunjukkan bahwa berpikir siswa bergaya belajar visual dalam memecahkan masalah pecahan melalui empat tahapan yaitu memahami masalah, menyusun rencana, melaksanakan rencana dan memeriksa kembali. Berikut ini penjelasan tentang berpikir siswa disetiap tahapan polya.

Tahap memahami masalah diperoleh sebagai berikut.

Subjek Visualmenerima informasi ketika memahami masalah yaitu denganmembaca dengan suara pelan atau keras sebanyak sekali atau berulangulang. mengolah informasi ketika memahami masalah yaitu dengan mengungkapkan masalah dengan kata-kata sendiri. Menyimpan informasi dengan mempertahankan informasi ketika memahami masalah yaitu dengan melakukan Pengulangan halyang diketahui dan ditanya. Memanggil kembali informasi ketika membaca dan menggali masalah yaitu dengan menjelaskan menurut bahasanya sendiri.

\section{Tahap menyusun rencana diperoleh sebagai berikut.}

Subjek Visualmemanggil kembali informasi ketika membuat rencana yaitudengan mengingat pengetahuan lain yang sudah dimilikinya ataukonsep yang sudah dikuasai untuk membuat rencana yaitu dengan cara menjumlahkannya. Mengolah informasi ketika membuat rencana yaitu muncul ide untuk memulai mengerjakan soal permasalah yang diberikan dan membuat rencana yang akan digunakan dalam pemecahan masalah. Menyimpan informasi dengan mempertahankan informasi ketika membuat rencana yaitu dengan mengatakan berulang-ulang rencana yang dibuat.

Tahap melaksanakan rencana penyelesaian diperoleh sebagai berikut.

SubjekVisual memanggil kembali informasi ketika melaksanakan rencanayaitu dengan mengingat rencana yang sudah dibuat.Subjek Visual mengolah informasi ketika melaksanakan rencana yaitu melaksanakan sesuai 
rencana yang dibuat. Subjek Visual menyimpan informasi dengan mempertahankan informasi ketika melaksanakan rencana yaitu mengulang pelaksanaan rencana.

\section{Tahap memeriksa kembali diperoleh informasi sebagai berikut.}

Subjek Visual memanggil kembali informasi ketika memeriksa kembalisolusi yang diperoleh yaitu dengan mengingat pelaksanaan rencana atausolusi yang sudah diperoleh. Subjek Visual mengolah informasi ketika memeriksa kembali solusi yang diperoleh yaitu dengan mengaitkan pengetahuan yang dimilikinya ketika memeriksa jawaban yang diperoleh. Subjek Visualmenyimpan informasi ketika memeriksa kembali solusi yang diperoleh yaitu dengan mengulang solusi yang diperoleh.

Hasil penelitian ini menunjukkan bahwa berpikir siswa bergaya belajar auditori dalam memecahkan masalah pecahan melalui empat tahapan yaitu memahami masalah, menyusun rencana, melaksanakan rencana dan memeriksa kembali. Berikut ini penjelasan tentang berpikir siswa disetiap tahapan polya.

Tahap memahami masalah diperoleh sebagai berikut.

SubjekAuditorimenerima informasi ketika memahami masalah yaitu denganmembaca dengan suara pelan atau keras sebanyak sekali atau berulangulang. Mengolah informasi ketika memahami masalah yaitu dengan mengungkapkan masalah dengan kata-kata sendiri. Menyimpan informasi dengan mempertahankan informasiketika memahami masalah yaitu dengan melakukan Pengulangan halyang diketahui dan ditanya. Memanggil kembali informasi ketika membaca dan menggalimasalah yaitu dengan menjelaskan menurut bahasanya sendiri.

\section{Tahap menyusun rencana diperoleh sebagai berikut.}

Subjek Auditorimemanggil kembali informasi ketika membuat rencana yaitudengan mengingat pengetahuan lain yang sudah dimilikinya ataukonsep yang sudah dikuasai untuk membuat rencana yaitu dengan cara menjumlahkannya. Subjek Auditori mengolah informasi ketika membuat rencana yaitu muncul ide untuk memulai mengerjakan soal permasalah yang diberikan dan membuat rencana yang akan digunakan dalam pemecahan masalah. Subjek Auditorimenyimpan informasi dengan mempertahankan informasi ketika membuat rencana yaitu dengan mengatakan berulang-ulang rencana yang dibuat.

Tahap melaksanakan rencana diperoleh sebagai berikut.

Subjek Auditori memanggil kembali informasi ketika melaksanakan rencanayaitu dengan mengingat rencana yang sudah dibuat.Subjek Auditori mengolah informasi ketika melaksanakan rencana yaitu melaksanakan sesuai

44 | FaLASIFA, Vol. 9 Nomor 1 Maret 2018 
rencana yang dibuat. Subjek Auditori menyimpan informasi dengan mempertahankan informasi ketika melaksanakan rencana yaitu mengulang pelaksanaan rencana.

Tahap memeriksa kembali diperoleh sebagai berikut.

Subjek Auditori memanggil kembali informasi ketika memeriksa kembalisolusi yang diperoleh yaitu dengan mengingat pelaksanaan rencana atausolusi yang sudah diperoleh. Subjek Auditorimengolah informasi ketika memeriksa kembali solusi yang diperoleh yaitu dengan mengaitkan pengetahuan yang dimilikinya ketika memeriksa jawaban yang diperoleh. Subjek Auditori menyimpan informasi ketika memeriksa kembali solusi yang diperoleh yaitu dengan mengulang solusi yang diperoleh. Hasil penelitian ini menunjukkan bahwa berpikir siswa bergaya belajar kinestetik dalam memecahkan masalah pecahan melalui empat tahapan yaitu memahami masalah, menyusun rencana, melaksanakan rencana dan memeriksa kembali. Berikut ini penjelasan tentang berpikir siswa disetiap tahapan polya.

Tahap memahami masalah diperoleh sebagai berikut.

Subjek Kinestetik menerima informasi ketika memahami masalah yaitu dengan membaca soal sambil menulis kembali soalnya. Subjek S3 mengolah informasi ketika memahami masalah yaitu dengan mengungkapkan masalah dengan kata-kata sendiri. Subjek Kinestetikmenyimpan informasi dengan mempertahankan informasiketika memahami masalah yaitu dengan melakukan pengulangan halyang diketahui dan ditanya. Subjek Kinestetikmemanggil kembali informasi ketika membaca dan menggalimasalah yaitu dengan menjelaskan menurut bahasanya sendiri.

Tahap menyusun rencana diperoleh sebagai berikut.

Subjek Kinestetik mengolah informasi ketika membuat rencana yaitu muncul ide untuk memulai mengerjakan soal permasalah yang diberikan dan membuat rencana yang akan digunakan dalam pemecahan masalah. Subjek Kinestetikmenyimpan informasi dengan mempertahankan informasi ketika membuat rencana yaitu dengan mengatakan berulang-ulang rencana yang dibuat.

\section{Tahap melaksanakan rencana diperoleh sebagai berikut.}

Subjek Kinestetik mengolah informasi ketika melaksanakan rencana yaitu melaksanakan sesuai rencana yang dibuat. Subjek Kinestetik menyimpan informasi dengan mempertahankan informasi ketika melaksanakan rencana yaitu mengulang pelaksanaan rencana.

\section{Tahap memeriksa kembali diperoleh sebagai berikut.}

Subjek Kinestetik mengolah informasi ketika memeriksa kembali solusi yang diperoleh yaitu dengan mengaitkan pengetahuan yang dimilikinya ketika 
memeriksa jawaban yang diperoleh. Subjek Kinestetik menyimpan informasi ketika memeriksa kembali solusi yang diperoleh yaitu dengan mengulang solusi yang diperoleh.

\section{KESIMPULAN}

Berdasarkan pertanyaan penelitian dan hasil analisis data yang telah diuraikan pada bab sebelumnya, maka simpulan dalam penelitian ini adalah:

Profil berpikir subjek bergaya belajar visual dan audiotori karakteristiknya sama dalam memecahkan masalah pecahan Memahami masalah dengan soal yang diberikan membacanya dengan suara pelan atau keras sebanyak sekali atau berulang ulang dan mengolah informasi dengan mengungkapkan masalah dengan kata-kata sendiri.Menyimpan informasi dengan melakukan pengulangan hal yang diketahui dan ditanya dan memanggilnya kembali informasi tersebut dengan menjelaskan menurut bahasanya sendiri, merencanakan dan melaksanakan penyelesaian, subjek memanggil kembali informasi dengan mengingat pengetahuan lain yang sudah dimilikinya atau konsep yang sudah dikuasai dengan menjumlahkannya dan dengan mengingat rencana yang sudah dibuat. Mengolah informasi dengan memunculkan ide untuk memulai mengerjakan soal permasalah yang diberikan, membuat rencana yang akan digunakan dalam pemecahan masalah dan melaksanakan sesuai rencana yang dibuat. melakukan menyimpanan informasi yaitu dengan mengatakan berulang-ulang rencana yang dibuat dan mengulang pelaksanaan rencana. Pada saat memeriksa kembali hasil penyelesaian, subjek mengingat pelaksanaan rencana atau solusi yang sudah diperoleh, mengaitkan pengetahuan yang dimilikinya ketika memeriksa jawaban yang diperoleh dan mengulang solusi yang diperoleh sedangkan subjek bergaya belajar kinestetik dalam memecahkan masalah pecahanmemahami masalah atau soal yang diberikan membaca soal sambil menulis kembali soalnya dan mengolah informasi dengan mengungkapkan masalah dengan kata-kata sendiri. Subjek juga menyimpan informasi dengan melakukan pengulangan hal yang diketahui dan ditanya dan memanggilnya kembali informasi tersebut dengan menjelaskan menurut bahasanya sendiri. Dalam merencanakan dan melaksanakan penyelesaian, subjek tidak melakukan proses pemanggilan kembali informasi. Subjek langsung mengolah informasi yaitu dengan memunculkan ide untuk memulai mengerjakan soal permasalah yang diberikan, membuat rencana yang akan digunakan dalam pemecahan masalah dan melaksanakan sesuai rencana yang dibuat. Subjek juga melakukan menyimpanan informasi yaitu dengan mengatakan berulang-ulang rencana yang dibuat dan mengulang pelaksanaan rencana. Pada saat memeriksa kembali hasil penyelesaian, subjek langsung mengaitkan pengetahuan yang 
dimilikinya ketika memeriksa jawaban yang diperoleh dan mengulang solusi yang diperoleh.

\section{DAFTAR PUSTAKA}

Gunawan. A. W. (2006). Genius Learning Strategy. Jakarta: Gramedia Pustaka Hasrul. (2009). "Pemahaman Tentang Gaya Belajar" Volume 1, No 2 Jurnal. Holisin, L. (2012). Profil Penalaran Siswa Sekolah Dasar Dalam Menyelesaikan masalah pecahan ditinjau dari perbedaan gender dan kemampuan matematika. (Disertasi doktor tidak dipublikasikan). Universitas NegeriSurabaya. http://blog.unsri.ac.id/zainab2011/filsafat-pendidikan/matematika-

Krulik, S \& Rudnick, J. A. (1995).The new sourcebook for teachingreasoning and problem solving in Elementary School.Boston:Allyn andBacon.

Orton, A. (1992).Learning mathematics issues, theory and classroom practice.

Polya, G. (1973). How To Solve It. A new Aspect of Mathematical Method. Princetown University Press. Princeton and Oxford.

Santrock, J. W. (2010). Psikologi Pendidikan Edisi Kedua. Jakarta: Kencana. sebagai-alat-berpikir-pada-aljabar/mrdetail/101949. Diakses pada tanggal

Siswono, T. Y. E (2002). Proses Berpikir Siswa Dalam Pengajuan Soal. Jurnal Matematika Atau Pembelajarannya, Tahun VIII. ISSN:0852-7792, Universitas Negeri Malang Konferensi Nasional Matematika XI. http://tatagyes.files.wordpress.com/2009/11/paper02 berpikir2.Pdf.

Siswono, T. Y.E. (2008). Model Pembelajaran Matematika Berbasis Pengajuandan Pemecahan Masalah Untuk Meningkatkan Kemampuan Berpikir Kreatif. Surabaya. Unesa University Press.

Soedjadi, R. (2000). Kiat Pendidikan Matematika Di Indonesia. Konstatasi Keadaan Masa Kini Menuju Harapan Masa Depan, Jakarta: Direktorat Jendral Pendidikan Tinggi, Departemen Pendidikan Nasional.

Solso., dkk. (2008). Psikologi Kognitif. Edisi kedelapan. Erlangga.

Sumardyono. (2011). Pengertian Dasar Problem Solving. https://erlisilitonga.files. wordpress.com/2011/12/pengertiandasarproblems olving smd.pdf.Diakses, 16 November 2015.

Susanto. (2008). Mahasiswa Field Independent dan Field Dependent Dalam Memahami Konsep Grup. Semnas matematika dan pendidikanmatematika: Universitas Negeri Yogyakarta Utama.

Zainab. (2012). Matematika Sebagai Alat Berpikir Pada Aljabar. (Online) http://ftunm.net/medtek/Jurnal\%20Medtek/Hasrul.pdf, diakses pada tanggal 14 November 2015.(Sec. ed.). London: Cassell.18 November 2015. Download Pada tanggal 16 November 2015 


\section{Khurin'in Ratnasari}

48 | FalAsIFA, Vol. 9 Nomor 1 Maret 2018 